\title{
Evaluation of the Seropositivity of Patients with Cystic Echinococcosis in Konya, Turkey
}

\section{Kistik Ekinokokkozlu Hastaların Seropozitifliğinin Değerlendirilmesi, Konya, Türkiye}

\author{
ĐSümeyye Başer1, (DAynur İsmayıl1, @Salih Maçin'1 \\ 'Selcuk University, Faculty of Medicine, Department of Medical Microbiology, Konya, Turkey
}

\begin{abstract}
Aim: Diagnosis of echinococcosis is based on clinical symptoms, imaging techniques and particularly on the detection of specific antibodies in serum specimens of patients. The aim of this study is retrospective evaluation of seropositivity in patients who is diagnosed as cystic echinococcosis.

Material and Method: In this study, serum samples of the patients, which were sent to the Medical Microbiology Laboratory from several clinics of the Selcuk University Medical Faculty Hospital between 01 January 2015- 01 July 2020, were evaluated in terms of cystic echinococcosis by using indirect hemaglutination test. The results were evaluated with a cut off titer $\geq 160$ of as recommended by the manufacturer. Results were evaluated by gender and ages.

Results: Cystic hydatid $(\mathrm{CH})$ was determined to be seropositive $332(21.6 \%)$ of 1543 patient samples. Seropositivity was found in 226 (14.7\%) of 933 female patients and in 106 (6.9\%) of 610 male patients. Seropositivity was mostly seen in 21-40 age group.

Conclusion: While there have been a number of animal studies, little information is available about the prevalence of cystic echinococcosis in humans in Turkey. Cystic echinococcosis continues to be a major public health problem in Konya province. Large scale prevention and control programs should be implemented against this disease.
\end{abstract}

Keywords: Hydatid cyst, echinococcosis, hemagglutination tests
Öz

Amaç: Ekinokokkoz teşhisi klinik semptomlara, görüntüleme tekniklerine ve özellikle hastaların serum örneklerinde spesifik antikorların saptanmasına dayanır. Bu çalışmanın amacı, kistik ekinokokkoz tanısı alan hastaların seropozitifliğinin geriye dönük olarak değerlendirilmesidir.

Gereç ve Yöntem: Bu çalışmada 01 Ocak 2015-01 Temmuz 2020 tarihleri arasında Selçuk Üniversitesi Tıp Fakültesi Hastanesi'nin çeşitli kliniklerinden Tıbbi Mikrobiyoloji Laboratuvarı'na gönderilen hastaların serum örnekleri indirekt hemaglütinasyon testi ile kistik ekinokokkoz açısından değerlendirilmiştir. Sonuçlar, kit prospektüsü doğrultusunda $\geq 160$ titerde olanlar pozitif şeklinde değerlendirilmiştir. Sonuçlar cinsiyet ve yaşa göre değerlendirilmiştir.

Bulgular: Kist hidatik (KH) 1543 hasta örneğinin 332'sinde (\% 21.6) kistik ekinokokkoz açısından seropozitif olduğu belirlenmiş̧ir. 933 kadın hastanın 226'sında $(\%$ 14,7) ve 610 erkek hastanın 106'sında $(\%$ 6,9) seropozitiflik saptanmıştır. Seropozitiflik en çok 21-40 yaş grubunda görülmüştür.

Sonuç: Çok sayıda hayvan çalışması yapılmış olsa da, Türkiye'de insanlarda kistik ekinokokoz prevalansı hakkında çok az bilgi mevcuttur. Konya ilinde kistik ekinokokkoz önemli bir halk sağlı̆ı sorunu olmaya devam etmektedir. Bu hastalığa karşı büyük ölçekli önleme ve kontrol programları uygulanmalıdır.

Anahtar Kelimeler: Hidatik kist, ekinokokkoz, hemaglütinasyon testleri 


\section{INTRODUCTION}

Cystic hydatid $(\mathrm{CH})$ is a zoonotic disease which is transmitted orally by taking Echinococcus eggs. The adult form of Echinococcus granulosus produces eggs by settling into the small intestine of dogs and wolves, which are the definitive hosts. Eggs in the cestode segment or in free form infect a variety of animals such as sheep, goats and cattle. ${ }^{[1]}$ When these eggs are taken by mouth, they pass through the stomach to the small intestine and become larvae. The larvae penetrate the gut wall and pass through various organs through the blood and lymph. It causes cyst formation in human organs such as liver and lung and leads to hydatid disease with high mortality. ${ }^{[2-4]}$

$\mathrm{CH}$ is an important public health problem in developing countries, especially where animal husbandry is intense and where sheep is consumed intensively. $\mathrm{CH}$ is endemic in Mediterranean countries, South American countries and most of Africa. ${ }^{[1]}$ It is widespread in our country and mostly found in Central Anatolia with a rate of 38.6\%. ${ }^{[2,3]}$

In addition combination of serology and imaging, serological tests are also used in the diagnosis of $\mathrm{CH}$. Serology is very valuable in uncertain cases. ${ }^{[4]}$ In addition to being used for diagnostic purposes, serological tests are also useful in the postoperative follow-up of the disease. ${ }^{[5]}$ Most tests used in serological diagnosis are in patient serum. It is based on the search for antibodies. ELISA and Indirect hemagglutination (IHA) techniques are frequently preferred due to their ease of application, low cost, high sensitivity and specificity. ${ }^{[4-6]}$

This study was carried out in order to retrospectively examine the seropositivity of patients with a preliminary diagnosis of hydatid cyst in our hospital by indirect hemagglutination test and to contribute to the knowledge about the disease in our region.

\section{MATERIAL AND METHOD}

In this study, the blood serum samples of a total of 1543 patients, which were sent to the Medical Microbiology Laboratory from several clinics of the Selcuk University Medical Faculty between 01 January 2015-31 July 2020 with the diagnosis of $\mathrm{CH}$. E. granulosus antibodies in serum samples were determined by indirect hemagglutination (IHA) method (Fumouze Laboratoires, France). $\geq 1 / 160$ serum titers were considered positive.

The study was carried out with the permission of Selcuk University Faculty of Medicine Local Ethics Committee approval was obtained (Date: 30,09,2020 number: 2020/435).

\section{RESULTS}

In our study, seropositivity was detected in 332 (21.6\%) of 1543 patients who were referred with a preliminary diagnosis of $\mathrm{CH}$. The highest seropositivity was detected in the 21-40 age group. Table 1 shows the distribution of patients with seropositivity according to age groups and gender. In our study, $176(53.01 \%)$ of 332 positive serum samples came from the general surgery, 34 (10.24\%) from chest diseases, and 37 (11.1\%) from other clinics (Table 2).

\begin{tabular}{lcccccc} 
Table 1. Distribution of seropositivity rates by age and gender \\
\cline { 2 - 7 } Age & \multicolumn{2}{c}{ Male } & \multicolumn{2}{c}{ Female } & \multicolumn{2}{c}{ Total Positive } \\
\cline { 2 - 7 } & $\mathbf{n}$ & $\%$ & $\mathbf{n}$ & $\%$ & $\mathbf{n}$ & $\%$ \\
\hline $0-6(\mathrm{n}: 55)$ & 5 & $(9.1)$ & 3 & $(5.4)$ & 8 & $(14.5)$ \\
$7-20(\mathrm{n}: 180)$ & 15 & $(8.3)$ & 27 & $(15.0)$ & 42 & $(23.3)$ \\
$21-40(\mathrm{n}: 389)$ & 32 & $(8.2)$ & 73 & $(18.8)$ & 105 & $(27.0)$ \\
$41-60(\mathrm{n}: 551)$ & 32 & $(5.8)$ & 81 & $(14.7)$ & 113 & $(20.5)$ \\
$\geq 61(\mathrm{n}: 368)$ & 22 & $(6.3)$ & 42 & $(11.4)$ & 64 & $(17.7)$ \\
Total (n:1543) & 106 & $(6.9)$ & 226 & $(14.7)$ & 332 & $(21.6)$ \\
\hline
\end{tabular}

Table 2. Distribution of seropositive samples by clinics

\begin{tabular}{lcc} 
Clinics & $\mathbf{n}$ & $\%$ \\
\hline General surgery & 176 & 53.01 \\
Pulmonary diseases & 34 & 10.24 \\
Gastroenterology & 20 & 6.02 \\
External Centers & 28 & 8.43 \\
Pediatric infection & 13 & 3.91 \\
Pediatric surgery & 10 & 3.01 \\
Infectious diseases & 14 & 4.21 \\
Others* & 37 & 11,1 \\
Total & 332 & 100 \\
\hline
\end{tabular}

*Brain and nerve surgery, Pediatric emergency, Pediatric gastroenterology, Hepatology, Nutrition service, Pediatrics, Dermatology, Internal Diseases, Hematology, Orthopedics, Radiology, Dermatology, Rheumatology, Medical oncology, Urology clinics.

\section{DISCUSSION}

Cystic hydatid disease is caused by larval forms of echinococcus. There are four species of echinococcus ( $E$. granulosus, E. multilocularis, E. vogeli, E. oligarthrus). Only E. granulosus and E. multilocularis cause disease in humans. The actual incidence of echinococcus worldwide is not evident. a total of 14,789 cases have been reported in Turkey in the 2001-2015 period. ${ }^{[5]}$

Indirect hemagglutination test is important in the diagnosis and follow-up of the treatment. It is used in the postoperative period to monitor the effectiveness of surgical treatment. With the healing of the disease, titers in the serum also gradually decrease but may remain positive for years. The increase in serology after years may indicate reinfection. ${ }^{[7]}$ In our country, seropositivity was found to be between $2.7 \%$ and $54.1 \%$ in ELISA, IHA and immunofluorescence studies in different regions. ${ }^{[8-16]}$ In our study, seropositivity was detected in 315 patients (21.9\%).

Conducted in our country, $\mathrm{CH}$ is higher in women than in men..$^{[3,16,17]}$ According to the study of Hakverdi et al. ${ }^{[18]}$ according to their study, the rate of $\mathrm{CH}$ was found to be $53.7 \%$ in women and $46.3 \%$ in men. In a study from the Central Anatolia Region, 56\% of the patients diagnosed with $\mathrm{CH}$ were reported as female and $44 \%$ as male. ${ }^{[19]}$ However, in a study conducted in Ankara, the rate of male patients was $51.2 \%$ and the rate of female patients was $48.8 \% .{ }^{[20]}$ In the literature, there are studies in which parasites are found to be equal in both genders. ${ }^{[14,19-22]}$ In our study, $24.3 \%$ female patients and $17.9 \%$ male patients were seropositive. 
When the studies performed in our country are examined, it has been reported that the disease is mostly seen in the 41-60 age group. ${ }^{[14,16,21,23,24]}$ In our study, similar to these results, the seropositivity rate was found in $113(20.5 \%)$ between $41-60$ age groups. When we evaluate the previous studies in our region, it has seen that our study has similar characteristics with other studies according to gender and age groups.

Some studies done in Turkey, liver involvement (44-73.3\%) were reported as the most common. ${ }^{[14,16,23]}$ Güreser et al. ${ }^{[24]}$ reported that $\mathrm{CH}$ positivity was found in $43.8 \%$ of the samples sent from general surgery, 21.9 infectious disease and 21.9\% gastroenterology clinic. Similarly, in our study, seropositivity was found mostly in the blood samples sent from general surgery (53.01\%) and chest diseases (10.24\%) clinics.

Since Konya and its surroundings are one of the places where agriculture and animal husbandry are common, this disease is an important public health problem in our region. Therefore, large scale control and protection programs should be implemented.

\section{CONCLUSION}

While there have been a number of animal studies, little information is available about the prevalence of cystic echinococcosis in humans in Turkey. Cystic echinococcosis continues to be a major public health problem in Konya province. Large scale prevention and control programs should be implemented against this disease.

\section{ETHICAL DECLARATIONS}

Ethics Committee Approval: For this research; Selcuk University Faculty of Medicine Local Ethics Committee approval was obtained (Date: 30,09,2020 number: 2020/435).

Informed Consent: All patients signed the free and informed consent form.

Referee Evaluation Process: Externally peer-reviewed.

Conflict of Interest Statement: The authors have no conflicts of interest to declare.

Financial Disclosure: There is no financial disclosure.

Author Contributions: All of the authors declare that they have all participated in the design, execution, and analysis of the paper, and that they have approved the final version.

\section{REFERENCES}

1. Eckert J, Deplazes P. Biological, epidemiological, and clinical aspects of echinococcosis, a zoonosis of increasing concern. Clin Microbiol Rev. 2004;17(1):107-35.

2. Altintas N. Past to present: echinococcosis in Turkey. Acta Trop. 2003;85(2):105-12.

3. Yazar S, Ozkan AT, Hokelek M, Polat E, Yilmaz H, Ozbilge H, et al. [Cystic echinococcosis in Turkey from 2001-2005]. Turkiye Parazitol Derg. 2008;32(3):208-20.

4. Ito A, Ma L, Schantz PM, Gottstein B, Liu YH, Chai JJ, et al. Differential serodiagnosis for cystic and alveolar echinococcosis using fractions of Echinococcus granulosus cyst fluid (antigen B) and E. multilocularis protoscolex (EM18). Am J Trop Med Hyg. 1999;60(2):188-92.
5. Ozkol M, Kilimcioglu AA, Girginkardesler N, Balcioglu IC, Sakru N, Korkmaz $M$, et al. A discrepancy between cystic echinococcosis confirmed by ultrasound and seropositivity in Turkish children. Acta Trop. 2005;93(2):213-6.

6. Gottstein B. Molecular and immunological diagnosis of echinococcosis. Clin Microbiol Rev. 1992;5(3):248-61.

7. McManus DP, Zhang W, Li J, Bartley PB. Echinococcosis. Lancet 2003;362(9392):1295-304.

8. Yilmaz H, Cengiz ZT, Cicek M. [Unilocular cyst hydatid cases diagnosed between 1998-2005 in the Parasitology Laboratory of Yuzuncu Yil University Research and Training Hospital]. Turkiye Parazitol Derg. 2013;37(4):249-51.

9. Esgin M, Aktas M, Coskun S. [The investigation of antibody presence in the sera of patients with a suspicion of cystic echinococcosis by using indirect hemaglutination test (IHA)]. Turkiye Parazitol Derg. 2007;31(4):283-7.

10. Aydin M, Adiyaman G, Dogruman-AI F, Kustimur S, Ozkan S. [Determination of anti-echinococcus IgG antibodies by ELISA in patients with suspected hydatid cyst]. Turkiye Parazitol Derg. 2012;36(2):61-4.

11. Cetinkaya Z, Ciftci IH, Demirel R, Altindis M, Ayaz E. A sero-epidemiologic study on cystic echinococcosis in midwestern region of Turkey. Saudi Med J. 2005;26(2):350-1.

12. Yazar S, Yaman O, Cetinkaya F, Sahin I. Cystic echinococcosis in Central Anatolia, Turkey. Saudi Med J. 2006;27(2):205-9.

13. Cetinkaya U, Hamamci B, Kaya M, Gucuyetmez S, Kuk S, Yazar S, et al. [Investigation of anti-Echinococcus granulosus antibodies in patients with suspected cystic echinococcosis]. Turkiye Parazitol Derg. 2012;36(2):5760.

14. Yazici V, Oruc T, Oren E, Ertabaklar H. [Retrospective evaluation of patients with probable cystic echinococcosis to the central laboratory of the Kocaeli Derince education and research hospital between 2009 and 2011]. Turkiye Parazitol Derg. 2012;36(4):219-21.

15. Karaman U, Miman O, Kara M, GicikY, Aycan OM, Atambay M. [Hydatid cyst prevalence in the region of Kars.]. Turkiye Parazitol Derg. 2005;29(4):238 40.

16. Ozekinci S, Bakir S, Mizrak B. [Evaluation of cystic echinococcosis cases given a histopathologic diagnosis from 2002 to 2007 in Diyarbakir]. Turkiye Parazitol Derg. 2009;33(3):232-5.

17. Akisu C, Bayram Delibas S, Yuncu G, Aksoy U, Ozkoc S, Bicmen C, et al. [Evaluation of IHA, ELISA and Western Blot tests in diagnosis of pulmonary cystic hidatidosis]. Tuberk Toraks. 2005;53(2):156-60.

18. Hakverdi S, Culha G, Canda MS, Yaldiz M, Altintas S. [Problem of cystic echinococcoss in Hatay]. Turkiye Parazitol Derg. 2008;32(4):340-2.

19. Kilic S, Babur C, Taylan Ozkan A. [Comparison of the results of indirect hemagglutination and ELISA methods for the cases prediagnosed as hydatid cyst disease]. Mikrobiyol Bul. 2007;41(4):571-7.

20. Celik T, Akarsu GA, Gungor C, Colak C, Ormeci N. Evaluation of antibodies against hydatid cyst fluid antigens in the post-treatment follow-up of cystic echinococcosis patients. Med Sci Monit. 2009;15(4):CR170-6.

21. Karadag A, Yanik K, Unal N, Odabasi H, Hokelek M. [Evaluation of materials sent due to suspected cystic echinococcosis to the parasitology laboratory of Ondokuz Mayis University Medical School between the Years 2005-2011]. Turkiye Parazitol Derg. 2013;37(1):28-31.

22. Gulsun S, Cakabay B, Nail Kandemir M, Aslan S, Atalay B, Sogutcu N, et al. Retrospective analysis of echinococcosis in an endemic region of Turkey, a review of 193 cases. Iran J Parasitol. 2010;5(3):20-6.

23. Miman O, Atambay M, Aydin NE, Daldal N. [The clinical, serological and morphological analysis of 91 patients with cystic echinococcosis following surgery]. Turkiye Parazitol Derg. 2010;34(3):179-83.

24. Gureser AS, Ozcan O, Ozunel L, Boyacioglu ZI, Taylan Ozkan A. [Evaluation of the radiological, biochemical and serological parameters of patients prediagnosed as cystic echinococcosis in Corum, Turkey]. Mikrobiyol Bul. 2015;49(2):231-9. 